\title{
FIESTA Y CELEBRACIONES LUCTUOSAS EN LA CATEDRAL DE SEVILLA (1685-1701)
}

\author{
DAVID CHILLÓN RAPOSO \\ Universidad de Sevilla
}

\begin{abstract}
Resumen
Tras el fallecimiento del arzobispo don Ambrosio Spinola y Guzmán en 1684 le sucedió en la mitra hispalense don Jaime de Palafox y Cardona, que había ocupado hasta entonces la silla de Palermo. Durante su gobierno, el prelado presidió importantes ceremonias en el principal de los templos de la archidiócesis, convirtiéndose la catedral de Sevilla en un escenario que dotaba de contenido y significado cualquier acontecimiento que marcaba la historia.
\end{abstract}

\section{Palabras clave}

Jaime de Palafox y Cardona, catedral de Sevilla, barroco sevillano, celebraciones luctuosas, exequias, arzobispos de Sevilla, Ariza, Carlos II, María Luisa de Orleáns, Inocencio XI.

\section{FEASTS AND MOURNING CEREMONIES IN THE CATHEDRAL OF SEVILLE (1685-1701)}

\section{Abstract}

After the archbishop don Ambrosio Spinola Guzman's death in 1684, don Jaime de Palafox y Cardona substituted him in Seville miter, who had always been in Palermo until that moment. During his command, he lead important ceremonies in the main archdiocese temple and the cathedral of Seville turned into a significant stage with a huge content and meaning in history.

\footnotetext{
Keywords

Jaime de Palafox y Cardona, cathedral of Seville, sevillian baroque, mourning ceremonies, funeral rites, archbishop from Seville, Ariza, María Luisa de Orleans, Inocencio XI.
} 
Tras el fallecimiento del arzobispo don Ambrosio Spínola y Guzmán el 14 de mayo de 1684, ${ }^{1}$ tomó posesión de la iglesia hispalense en sede vacante el deán de la catedral don Francisco Domonte y Verastegui el día 15 de febrero de $1685,{ }^{2}$ en nombre de don Jaime de Palafox Rebolledo y Cardona, hasta entonces obispo de Palermo, una vez que el papa Inocencio XI emitió las correspondientes bulas. ${ }^{3}$ El nuevo prelado llegó a Sevilla el 14 de abril de 1685, víspera del Domingo de Ramos, para hacerse cargo de la sede hispalense por expreso deseo del rey Carlos II, quién instó al papa a prescindir del más incansable de sus ministros como obispo de Palermo. En palabras del Sumo Pontífice, don Jaime de Palafox y Cardona había sido "brazo invencible de la Iglesia, y firmísima columna de la inmunidad eclesiástica". ${ }^{4}$

La sede sevillana estaba vacante desde el fallecimiento del anterior arzobispo en mayo del 84, y en agosto de ese mismo año don Jaime de Palafox y Cardona escribió al cabildo de la catedral anunciándole que era electo a la sucesión de la mitra hispalense. A pesar de la rapidez de la comunicación, transcurrirá algo más de un año hasta recibirse en Sevilla las bulas de Roma. ${ }^{5}$ En enero del año siguiente el arzobispo electo se dirigió al cabildo agradeciéndole las atenciones que en su nombre le había dispensado en Roma el señor don Francisco Álvarez. ${ }^{6}$ Los agasajos que recibió el prelado no debieron ser pocos a juzgar por la cantidad económica que el cabildo había dispensado para tales fines, para los que se libró 2.000 reales de plata que procedían de la mesa capitular, 6.600 reales de vellón para gastos específicos de los homenajes, más 3.300 reales procedentes del expolio del arzobispo Spínola. ${ }^{7}$ A partir de entonces se inicia una continua correspondencia entre el prelado y el cabildo eclesiástico por medio del canónigo don Juan Antonio del Alcázar. El 22 de enero, Palafox notificaba en otro correo que transmitía poderes al señor deán para gobernar la Iglesia de Sevilla hasta su llegada a la ciudad, pidiéndole a don Antonio del Âlcázar que le agradeciera sus ocupaciones en el gobierno de la catedral. ${ }^{8}$

El cabildo dispuso que el sábado 14 de abril de 1685 se celebrase la ceremonia de ingreso y juramento. Según la costumbre, dicho día se oficiarían completas, solemnes, maitines y laudes, y después saldrían los capitulares revestidos con capas pluviales a la puerta de la Asunción de la catedral para recibir al arzobispo, en donde don Jaime de Palafox y Cardona juraría su cargo con la disposición que se había practicado en ocasiones semejantes. Para

${ }^{1}$ ORTIZ DE ZÚÑIGA, 1796: Tomo V, 381-382.

${ }^{2}$ Archivo de la Catedral de Sevilla (A.C.S.), Libros de Actas Capitulares del Cabildo de la Santa Iglesia Catedral de Sevilla, 1685: 19, Reunión del cabildo del miércoles, 14 de febrero de 1685.

${ }^{3}$ Estas bulas se emitieron en noviembre de 1684 y otorgaban además a don Jaime de Palafox y Cardona ciento treinta y siete ducados y medio de oro como "cámara de pensión" por hacerse también cargo del obispado de Calahorra.

${ }^{4}$ MORGADO, 1906: 582.

${ }^{5}$ ORTIZ DE ZÚÑIGA, 1796: Op. cit., tomo V, 386.

${ }^{6}$ A.C.S., Autos Capitulares, 1685: Op. cit., 4, en cabildo reunido el miércoles, 10 de enero de 1685.

7 A.C.S., Autos Capitulares, 1686: Op. cit., 12v, 13r, 14r y 15v, en cabildo reunido el miércoles, 30 de enero de 1686. Un año después el cabildo se reunió para satisfacer los pagos referentes a los agasajos que recibió en Roma el arzobispo Palafox; A.G.A.S., "Carta de don Pedro de Ormaechea Garai de Mendiola a don Jaime de Palafox y Cardona sobre diversos temas, entre ellos sobre el expolio del arzobispo Spínola, en Madrid con fecha 1 de septiembre de 1693" en Correspondencia escrita por el arzobispo don Jaime de Palafox y Cardona (1685- 1695), Fondo arzobispal, Sección II Gobierno, Serie Asuntos Despachados, Legajo 15.954, Expediente 1, doc. s/f. La situación económica del cardenal Spínola fue oscura tras su muerte, y posteriormente el arzobispo Palafox decidió investigarla, "En lo que vuestra Ilustrísima me manda remita testimonio de que en cuanto se arrende por la cámara apostólica el expolio del señor Spínola, he estado con el secretario apostólico de ella, y lo primero dice que no se dará dicho testimonio sin que se exprese por petición el efecto para que se pide. Lo segundo dice que no se arrendó porque no hubo quien hubiese querido entrar en el respeto de haber quedado más deudas que efectos, en cuya consideración, si acaso vuestra Ilustrísima tuviere noticia de no ser así lo último, y de haberse arrendado, será menester que vuestra Ilustrísima mande escribirme para que efecto se haya de pedir el testimonio, y si se pidiese en nombre de su Ilustrísima”.

${ }^{8}$ Idem: 10, en Actas del cabildo reunido el lunes, 22 de enero de 1685. Como se dijo, el deán tomó posesión del cargo el día 15 de febrero de ese mismo año. 
todo lo concerniente a este acto se nombró un comité que recibiría al prelado cuando llegase a la ciudad, formado por los canónigos don Luís Federigui, arcediano de Carmona, don Juan Antonio del Alcázar y el racionero don Juan Bonifás. ${ }^{9}$ Esta diputación recibió a Palafox con grandes agasajos en Carmona, predicándose sermones panegíricos donde se exaltaba la grandeza del eclesiástico y la buena suerte de la archidiócesis por tener un prelado de ejemplar virtud. En un acto puramente protocolario, el deán pidió perdón por los posibles errores cometidos durante el ejercicio de su gobierno en sede vacante, dando por concluida su función. ${ }^{10}$ Como caso curioso, citar que a don Jaime de Palafox se le olvidó en el convento de la Encarnación de Carmona su palio y el armiño, dignidad concedida por el Papa para arraigar a ciertos prelados a la cátedra de San Pedro. ${ }^{11}$

Una vez llegado el arzobispo a Sevilla recibió una carta de su secretario en la corte de Madrid, don Pablo Ressi del Castillo, con fecha de 22 de mayo de 1685. En ella, le informaba de diferentes cuestiones y le mandaba 120 reales de anticipo para que se lo diese al tesorero de la Capilla Real, ya que el arzobispo debía dar la citada cuantía a la sede hispalense a su llegada, sin mencionar el documento en concepto de la deuda. En cualquier caso, cita el documento, que la cuenta de los gastos de don Jaime de Palafox durante su viaje de Italia a España fue tremendamente modesta y austera. ${ }^{12}$

El año de 1686 traerá el desafortunado fallecimiento de don Diego del Castrillo, confesor y amigo de don Jaime de Palafox. Esta figura fue decisiva en el desarrollo eclesiástico de la carrera de Palafox. Murió el arzobispo de Zaragoza el 9 de junio, habiendo ocupado cargos relevantes en la administración eclesiástica como canónigo de la catedral de Sevilla, como auditor en el tribunal de la Rota y como obispo de Cádiz, de donde pasó finalmente a la diócesis cesaraugustana. Fue don Diego quien impulsó a Palafox a tomar la mitra del obispado de Palermo y no hay duda de que mediase, gracias a sus buenas relaciones con la monarquía y con el papado, para su elección como cabeza de la archidiócesis hispalense. Así pues, el fallecimiento de su protector produjo una gran congoja al arzobispo y éste decidió realizar una ceremonia solemne en la catedral en la que recordó los grandes logros de este ilustre personaje.

\footnotetext{
${ }_{9}$ Idem: 35, en cabildo celebrado el jueves 5 de abril de 1685.

${ }^{10}$ Idem: 38, en cabildo celebrado el mismo sábado día 14 de abril de 1685

11 A.G.A.S., "Carta de don Pedro Valero a don Jaime de Palafox y Cardona sobre el palio de su Ilustrísima, con fecha de Madrid 10 de abril de 1685", en Correspondencia escrita por el aryobispo don Jaime de Palafox y Cardona (1685-1695), Fondo arzobispal, Sección II Gobierno, Serie Asuntos Despachados, Legajo 15.954, Expediente 1, doc. s/f. "Y habiéndose quedado por olvido en el convento de la Encarnación el palio de su Ilustrísima, envió mi señora la priora el martes pasado recado a don Juan de Terán para ver si podía ir a recogerlo con el correo ordinario, dificultolo don Juan respecto hasta el jueves siguiente pasado que me lo envió a decir su señoría la madre María, y con el cuidado que estaba de lo que perjudicaba a su Ilustrísima este olvido, sentí no haberlo sabido el martes, pues no hubiera tenido inconveniente haber enviado el palio con el correo ordinario para que lo tuviera su Ilustrísima en su poder. Y no habiendo quedado más arbitrio para la seguridad y brevedad de esta reunión que la de despachar correo extraordinario, me pareció suspenderlos hasta la última hora de precisión por si esto se podía lograr sin costa alguna, con la ocasión de algún extraordinario que se despachase por su majestad. Esto no se ha podido lograr hasta ahora, y siendo la última que hay, para que vuestra Ilustrísima no se halle con el sin sabor de no poder celebrar el Domingo de Ramos me ha parecido, por mi obligación por el precepto de mi señora la madre María, y por las instancias de mi señora la priora, despachar este extraordinario. No obstante, no venir en ello don Esteban, quien ha rehusado dar dinero para ello, y aunque también lo hiciera por excusar a vuestra Ilustrísima este gasto, me ha parecido pensar más en el desazón con que vuestra Ilustrísima se hallaría, no pudiendo lograr la función del Domingo de Ramos, a que se añade la suma pena con que he visto por la presunción de satisfacer a mi señora la madre María, y también a mi señora la priora, que me dijo despachase el extraordinario, que su señoría dará el dinero para él; No me pareció justo permitirlo, despachándole yo, como lo hago, y suplico a vuestra Ilustrísima dispense esta determinación, si tuviere por los motivos que le llevo referidos me han movido a ello. También remito con el mismo extraordinario una caja en que van las dos en que van las dos que quedaron olvidadas en que están el pectoral y los tres anillos de su Ilustrísima".

12 A.G.A.S., "Carta de don Pablo Ressi del Castillo al arzobispo de Sevilla, don Jaime de Palafox y Cardona, con fecha de 22 de mayo de 1685", en Correspondencia escrita por el arzobispo don Jaime de Palafox y Cardona (16851695), Fondo arzobispal, Sección II Gobierno, Serie Asuntos Despachados, Legajo 15.954, Expediente 1, doc. $\mathrm{s} / \mathrm{f}$.
} 
El miércoles 20 de noviembre de 1686 se reunió el cabildo de la catedral de Sevilla, y con la solemnidad que la ocasión requería el deán dio noticia del fallecimiento de la marquesa de Ariza doña María Felipa de Cardona y Ligny, madre del prelado. Se acordó que el canónigo don Juan de Soto fuese hasta la villa de Aracena con un cortejo fúnebre de criados encapuchados con túnicas negras, por ser allí donde se encontraba Palafox realizando una de sus visitas pastorales a las iglesias de su arzobispado, con el fin de hacerle sentir el profundo pesar que su cabildo sentía ante la enorme pérdida. Soto tuvo el encargo de entregar al arzobispo una carta en mano escrita por el don Juan del Alcázar y rubricada por todo el cabildo donde se expresaba toda su congoja ante la pérdida. Asimismo se mandó escribir otra carta al marqués de Ariza, hermano de don Jaime, dando el pésame por la muerte de su madre la marquesa. Además el cabildo, en señal de duelo, ordenó doblasen las campanas de la Giralda y de todas las iglesias de la diócesis en señal de luto durante todo el día por la muerte de una grande de España. Siete días más tarde se leyó la respuesta que el arzobispo dio al cabildo en agradecimiento por el recordatorio que hicieron de su madre, por las muestras de dolor manifestadas y por todas aquellas atenciones que había recibido. ${ }^{13}$

La muerte no tardó en visitar otra vez la casa de los Ariza. Un año más tarde, el 24 de diciembre de 1687 se anunció el fallecimiento de una de las hermanas del arzobispo, la marquesa de la Casta, dicen la más querida y cercana al prelado. El deán convocó un cabildo extraordinario para anunciar la noticia y proceder en la forma ordinaria requerida en estos casos en referencia a los actos luctuosos que debían celebrarse, por lo que se nombró al racionero don Juan Soto para que fuese al encuentro del arzobispo en la localidad de El Coronil y ofrecer el pésame del cabildo por la muerte de su hermana, ya que también se encontraba fuera de Sevilla haciendo su visita al obispado. El arzobispo agradeció al cabildo las atenciones, y "después de asegurar a vuestras señorías que quedo con el reconocimiento que merece esta demostración paso a suplicar continúen sus oraciones persuadiéndose que yo estoy siempre a su servicio como debo, y que en las mías, aunque tibias se mantiene igual el cuidado de rogar a Dios". ${ }^{14}$ La noticia llego a Sevilla a través de una carta remitida por don Pablo Ressi a don Jaime de Palafox y Cardona en la que trataba diferentes temas, fechándose en Madrid el 16 de septiembre de 1687. Ressi decía en ella que "a mi señora la marquesa de la Casta dio ayer a mediodía un accidente tan fuerte de que fue Dios servido llevársela inmediatamente, siendo caso bien lastimoso. Y porque mi obligación manifiesta a vuestra Ilustrísima la parte de pena que como ha criado suyo me ha tocado". Además, informaba al prelado que habían llegado a sus manos "los regalos de chocolate y aceitunas que de orden de su Ilustrísima me remite para diferentes personas que contiene la relación, don Juan Gutiérrez; los cuales repartiré luego en virtud de dicha memoria como lo he empezado a hacer en el poco tiempo que he tenido desde que los recibí hasta ahora”. El cabildo y el arzobispado celebraron los actos de una manera austera, como era la condición del propio arzobispo en aquellos temas que él entendió como íntimos y personales. ${ }^{15}$

Sin embargo, el 12 de febrero de 1689 murió en Madrid, a los veintisiete años de edad, doña María Luisa de Orleáns, primera esposa del rey Carlos II. Don Antonio de Zúpide y Aponte informó a los cabildos de la ciudad del fallecimiento de la reina a través de una carta fechada a 25 de febrero de 1689, donde se pedía por reales cédulas que celebrasen las correspondientes honras fúnebres por la soberana en la catedral y en las iglesias de toda la diócesis de Sevilla. ${ }^{16}$

13 A.C.S., Autos Capitulares, 1686: Op. cit., 86 y 77v, en cabildos celebrados el miércoles 20 y miércoles 27 de noviembre de 1686.

14 A.C.S., Autos Capitulares, 1687-1688: Op. cit., 146r y 1v, en cabildos celebrados el miércoles 24 de diciembre de 1687 y 3 de enero de 1688.

15 A.G.A.S., "Carta de don Pablo Ressi a don Jaime de Palafox y Cardona sobre diferentes temas, con fecha de Madrid 16 de septiembre de 1687", en Correspondencia escrita por el arzobispo don Jaime de Palafox y Cardona (16851695, Fondo arzobispal, Sección II Gobierno, Serie Asuntos Despachados, Legajo 15.954, Expediente 1, doc. $\mathrm{s} / \mathrm{f}$.

16 ORTIZ DE ZÚÑIGA, 1796: Op. cit., tomo V, 412. 
La catedral conoció la noticia oficialmente el 7 de marzo a través de una carta real, y esa misma tarde se ofició un responso solemne dirigido por el arzobispo don Jaime de Palafox. Tras el acto, el cabildo mandó tocar las campanas de la Giralda por 24 horas y 7 en las iglesias de la ciudad, anunciándose también rezos cantados entre los coros de la catedral, siguiendo el manual dado por el arzobispo don Diego de Deza. Acabados los oficios y sin más demora el procurador mayor de la ciudad pidió licencia al eclesiástico para introducir en el templo los materiales precisos para la construcción del túmulo que se debía realizar entre los coros de la catedral en memoria de la difunta Reina. El consistorio quiso colaborar conjuntamente en estos trabajos con el cabildo para acelerar el proceso de creación, y para ello los diputados de la ciudad se pusieron a disposición de los oficiales de fábrica de la catedral colaborando hasta concluir el catafalco. El cabildo encargó además al maestro de capilla una nueva composición musical para la vigilia y las honras de la soberana que otorgasen mayor solemnidad a las celebraciones de tan triste suceso. ${ }^{17}$ Las exequias se oficiaron los días 29 y el 30 de ese mismo mes, presidiendo los actos el prelado. El sermón corrió a cargo del padre Juan de San Bernardo, de la orden tercera de San Francisco, lector jubilado, calificador del Santo Oficio y exprovincial de Andalucía. ${ }^{18}$ Los repiques de las campanas se escucharon en toda la ciudad, y además se erigió un gran túmulo funerario en memoria de la difunta reina. ${ }^{19}$

Para asegurar el linaje de los Austria en España se casó el rey Carlos II en segundas nupcias con la princesa palatina Mariana de Neoburgo, un matrimonio de estado que consolidaba una alianza política entre el Imperio austriaco y los reinos hispánicos, y que además auspiciaba el nacimiento de un heredero a la Corona, pero que nunca llegaría. Doña Mariana de Neoburgo se casó por poderes el 28 de agosto de 1689 en la corte de Viena a los veintidós años de edad. El matrimonio se ratificó en Valladolid el 22 de mayo del año siguiente, y el 26 de septiembre se informó a los cabildos de Sevilla de este hecho, celebrándose durante tres días consecutivos festejos por el real matrimonio. Así, hubo repique de campanas, luminarias en la Giralda, en la catedral y en toda la ciudad.

Otra importante muerte marca el año de 1689. El día 12 de agosto expiró en la ciudad de Roma, a los sesenta y ocho años de edad otro personaje decisivo en la carrera eclesiástica de Palafox, el papa Inocencio XI, después de trece años de pontificado. La noticia llegó a Sevilla el día 5 de septiembre ordenándose un toque de campanas solemne en la Giralda, al igual que lo fue el responso que ofició el arzobispo entre los dos coros. Desde el año de 1676 no se celebraban en Sevilla unas honras fúnebres en honor de un Sumo Pontífice, por lo que el cabildo estableció que se realizase según el ceremonial romano en la misma forma que se dispusieron las de Clemente X. De esta manera se inició la fábrica del túmulo funerario del difunto Papa, en el cual se implicó personalmente el arzobispo encargando las obras al canónigo y arcediano de Jerez don Fernando Santillán, familiar suyo, y al racionero don Luis Dávila. El cabildo dispuso que se acometiesen todos los gastos pertinentes al respecto para dar mayor solemnidad y lustro a los tristes acontecimientos y mandó "que el clavicímbano se aderece y sirva para las honras de su Santidad, y dio consentimiento a los dichos señores para que ajusten a precio competente el que dicho instrumento esté corriente para las funciones que se ofreciesen". ${ }^{20} \mathrm{El}$ arzobispo don Jaime de Palafox ofició en los días 26 y 27 de septiembre las solemnes exequias del que en otro tiempo fuese su mentor y otorgante de sus dignidades, como así lo afirma en su propio testamento: "Al Real Monasterio de Nuestra Señora de Piedra del orden del dulcísimo Padre Señor Bernardo en el Reyno de Aragón, antiguo entierro de la casa de Hariza, y donde están las cenizas de mis padres y diversos hermanos, e remitido el cuerpo de San Inocencio Martyr, por muestra de la devoción que le

17 A.C.S., Autos Capitulares, 1689-1690: Op. cit., 25v-26r, 32v-33, en los cabildos celebrados el 7, 17 y 22 de marzo de 1689.

18 BAENA GALLÉ (1992): 51-53.

19 Breve relación de las exequias que la muy Noble y muy Leal Ciudad de Sevilla dedicó a su Reina Doña María Luisa de Borbón, que sea en gloria, en el dia 30 de marzo de 1689. En Sevilla: por Juan Francisco de Blas.

20 A.C.S., Autos Capitulares, 1689-1690: Op. cit., 100v, 102, 107v-108 y 110v, en cabildos celebrados el 5, 9, 23 y 26 de septiembre de 1689. 


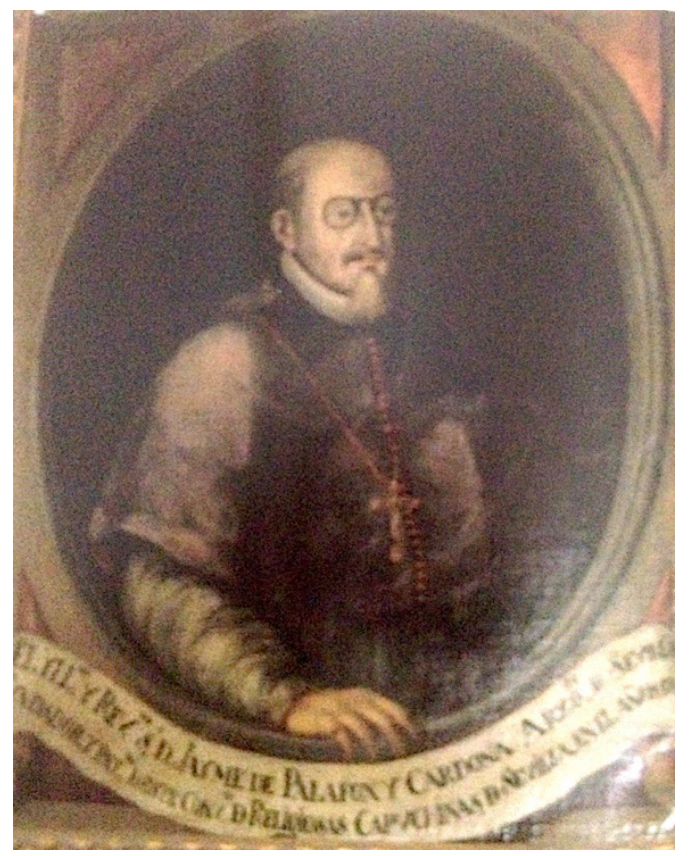

Fig. 1. Anónimo Sevillano. Primera mitad del siglo XVII. Retrato de Don Jaime de Palafox y Cardona, arzobispo de Sevilla (1685-1701). Sacristía del convento de Santa Rosalía. Sevilla.

profeso, y por habérmele dado en Roma la Santidad del Beatísimo Padre y Señor Inocencio XI, mi gran favorecedor, y por cuanto las obligaciones precisas de la Dignidad no me han dado lugar a colocar la urna de plata, bronces dorados y cristales en que iba puestos, en el lugar de adorno de Capilla, que pide tal Reliquia, suplico al Señor Abad y Reverendos Monjes de aquella Real Casa me perdonen y perfeccionen con su gran Religión lo que yo no he podido y executen conmigo su gran caridad, teniendo presente mi necesidad en sus santos sacrificios y oraciones". ${ }^{21}$

El 6 de octubre de 1689 fue elegido Papa el cardenal veneciano Pedro Octobono, quien adoptaría el nombre de Alejandro VIII. Don Jaime de Palafox y Cardona fue informado a través de una diputación nombrada desde Roma por el arcediano de Carmona y canónigo de la catedral don Luís Federigui. Éste portaba una carta que fue leída en Sevilla el 15 de noviembre de ese mismo año. El objeto de la misiva no fue otro que informar al arzobispo para que diese las órdenes oportunas en la organización y la preparación de los fastos en honor del nuevo pontífice y la exaltación de su Iglesia. Los actos fueron diversos, ya que se colocaron luminarias en la ciudad y se adornó el altar mayor y la capilla de San Pedro, se celebró una misa solemne en la catedral que ofició el propio arzobispo, se organizó una procesión en la catedral a la que acudieron "el clero, cruces y beneficiados" y donde se entonó el Te Deum laudamus, repicando al unísono las campanas de la catedral y las de todas las iglesias de Sevilla, y de los templos de la archidiócesis.

Quiso el prelado introducir en Sevilla la devoción por santa Rosalía, patrona de Palermo. Para ello encargó a fray Juan de San Bernardo en el año de 1689 una biografía que relatase las virtudes de la santa y la colocación de un relicario que donaría para un nuevo altar en la iglesia conventual de la Orden Tercera. ${ }^{22}$ Además, Palafox consiguió que se rezase a la advocación panormitana en la catedral y en su palacio, con oraciones y rituales específicos, aprobados en la Sagrada Congregación de Ritos en Palermo, en 1666 y en Sevilla, en 1685. El día 7 de septiembre de 1689, también en la catedral, se celebraría misa y procesión de capas para recibir el busto-relicario de plata de la santa que el prelado había regalado a la

21 Archivo Histórico de Protocolos Notariales de Sevilla (A.H.P.N.S.), Testamento de Don Jaime de Palafox y Cardona, 1701: 543 v.

22 SAN BERNARDO, fray Juan: Vida y milagros de Santa Rosalia Virgen. En Sevilla: por Thomás López de Haro, 1689. 
catedral y que procesionaría bajo palio, ${ }^{23}$ sostenido por cuatro acólitos, todo ello financiado por el prelado con dotaciones económicas importantes. ${ }^{24}$

$\mathrm{Al}$ año siguiente de ser nombrado obispo de Roma, el 14 de febrero de 1690 el deán dio cuenta al cabildo en nombre del arzobispo como había llegado una carta de Alejandro VIII a su poder en la que se concedía un jubileo en la archidiócesis de Sevilla "en cuanto a la extensión de los rezos de los señores San Isidoro y San Leandro, arzobispos de esta Santa Iglesia" por un periodo de dos semanas. Palafox propuso que se empezase cinco días después de la recepción de la misiva, y además de celebrar la noticia por el contenido del escrito pidió a los capitulares que se hiciese un esfuerzo por llevar a cabo esta celebración el día señalado. El cabildo aceptó la propuesta y encargó a la diputación de ceremonias que se adornase el altar mayor "en la forma que es estilo cuando hay semejantes jubileos". Aprovechando esta coyuntura el cabildo elevó una súplica al Papa pidiendo que "se dignase conceder a San Isidoro oficio doble de precepto de segunda clase con octava para los reinos de España, y doble de precepto para toda la Iglesia Universal. Y a San Leandro oficio doble para todos los reinos de España, como ahora lo es el oficio de Isidoro". Por ello se pidieron cartas al Rey, a los obispos y al cabildo secular para que cooperasen en la solicitud al Papa "del mayor y merecido culto de tan esclarecidos santos". El cabildo envió al prior don Jacinto Luarca, al canónigo don Alonso Benito de Medina y al racionero don Juan Bonifaz para que solicitase al arzobispo un informe para adjuntarlo al expediente que había elaborado el cabildo al respecto. El arzobispo emitió un documento donde exaltaba las virtudes de los santos y apoyaba la justificación que pretendía el cabildo de los dos arzobispos de Sevilla. ${ }^{25}$

Sin embargo, el pontificado del papa Alejandro VIII fue muy breve, ya que la muerte le sobrevino en Roma el 1 de febrero de 1691, recibiéndose la noticia en Sevilla el 12 de marzo de ese mismo año. A través de las Actas Capitulares conocemos cómo fue sorprendido el cabildo por el triste suceso en una procesión que se estaba celebrando y de cómo se convocó una reunión extraordinaria en urgencia para informar a todos los capitulares del fallecimiento con el fin de poder organizar el aparato oportuno en la mayor brevedad posible. Con toda solemnidad el cabildo celebró un responso presidido por el deán en memoria del Pontífice en el que estuvo asistido por el maestro de ceremonias y un colegial que además recitó las oraciones. Tras el acto y como era costumbre se mandó tañer la campana mayor de la torre sesenta veces para informar a la feligresía, prosiguiendo luego de otro toque con el doble de repeticiones por espacio de 24 horas. El provisor avisó inmediatamente al resto de las iglesias de la ciudad para que doblasen en respuesta a la señal de la catedral. Luego todos los miembros el cabildo hispalense fueron a besar la mano del prelado para invitarle a oficiar otro responso que se celebraría esa misma tarde después de completas entre los dos coros. El pavimento de este espació se cubrió con tapices rojos, y se colocó en medio una tarima alta cubierta de alfombras carmesíes que resaltaban los símbolos vaticanos de la tiara y las dos llaves cruzadas. Se pusieron "cuatro gigantes de plata" en cada esquina que iluminaron con sus hachones el emblema de San Pedro, y se vistió el altar mayor de primera clase con un frontal negro, cuyo aparato duraría las 24 horas que doblase la torre. La misa tuvo acompañamiento de órgano y cantos corales, y tras ella el cabildo se reunió en el presbiterio para rogar a Dios pro electione summi pontificis. Tres días después se informó al cabildo de lo que se había desarrollado en las honras del anterior Papa, y se decidió que los actos luctuosos por la muerte de Alejandro VIII se realizasen de la misma manera que se hicieron en las del papa Inocencio XI, y que se celebrarían los días 28 y 29 de ese mismo mes. Las funciones fueron presididas por el arzobispo como cabeza de la Iglesia Hispalense, y en ambas lució ricos pontificales que otorgaron mayor solemnidad a las honras fúnebres. Los responsables de fábrica dispusieron rápidamente todo lo necesario para la elevación del túmulo, y se nombró

23 ARENILLAS, 2007: 278-279.

${ }^{24}$ Esta noticia fue recogida por ACEVEDO, 1701: 27; La descripción de gastos se describe en A.C.S., Dotación y memoria de gastos para la fiesta de Santa Rosalia en la Catedral de Sevilla, Fondo Administración, Sección Gobierno, Serie Asuntos Despachados, Legajo 3, 1655-1700.

25A.C.S., Autos Capitulares, 1690: Op. cit, 15v y 16-17r, en cabildo celebrado el 14 de febrero de 1690. 
una diputación formada por el maestrescuela don Andrés de Ybarburu, por el canónigo don Bernardo de Urbina y por el doctor don Miguel Guixarro para que fuesen a invitar al cabildo secular e informar al prelado que ratificase las decisiones tomadas. ${ }^{26}$

Simultáneamente a la celebración de las honras fúnebres por el papa Alejandro VIII se produjeron otra serie de celebraciones en la ciudad presididas por el arzobispo Palafox y que marcarían su prelatura. Se hicieron en la ciudad de Sevilla unas rogativas por "estar padeciendo en estos reinos la más lamentable calamidad que les podía acontecer, que era la falta de sucesión del rey nuestro señor, que Dios guarde, por lo que sería muy conveniente hacer alguna demostración pública para aplacar la ira del cielo, y alcanzar de su divina majestad la sucesión que tanto deseaba para bien de toda la cristiandad". Por ello, el cabildo mandó el día 26 de marzo descubrir al Santísimo en el altar mayor de la catedral, estando adornado e iluminado como era costumbre en el día de Pentecostés, y tras los oficios de tercia se hizo procesión pública y solemne de rogativas por las gradas de la catedral, "yendo por la nave de la Antigua, puerta grande, saliendo por la puerta del bautismo y entrando por la puerta de la Granada, y se haga estación en la capilla de la virgen de los Reyes, y se finalice la letanía en el altar mayor con las oraciones de rogativa que corresponde a la función". Debido a la importancia de la rogativa el arzobispo acudió al cortejo acompañado de todas las cruces parroquiales y el clero de las parroquias, que acompañarían en su salida extraordinaria a la Virgen de los Reyes para darle mayor solemnidad a esta función. Después se hizo una misa mayor presidida por el arzobispo vestido con pontificales blancos, y acompañado por todos los capitulares con sus capas pluviales blancas, en la forma que se hacía el día de Pentecostés. También se acordó que desde esa tarde se rezase en comunidad en la capilla de Nuestra Señora de los Reyes, y se concluyesen estos rezos el día de la Encarnación. Se nombró al prior don Jacinto de Luarca, al canónigo don Gonzalo de Estrada y al racionero don Luís Dávila y Medina para que viesen al prelado e invitarle a asistir a las plegarias. Cuando volvió la diputación dijo que "su Ilustrísima había celebrado con sumo aprecio la resolución del cabildo y que concurriría con mucho gusto a esta función". ${ }^{27}$

26 A.C.S., Autos Capitulares, 1691-1692: Op. cit., 34, en cabildos celebrados el 12 y 15 de marzo de 1691.

27 Idem: 36-37, en cabildos celebrados los días 17, 21 y 22 de marzo de 1691. En este último cabildo se detalla la procesión:"Que el dicho día de la Anunciación ande la campana de prima de 6 a 7, y por cuanto el señor arzobispo gusta de celebrar de pontifical la tercia, procesión y misa, en la tercia se guarde el orden regular de pontifical. Que acabada la tercia se empiece la procesión de rogativa con letanías, diciéndose en el coro la Ana Exurge, y en el altar mayor la oración por su Ilustrísima. Que todo el cabildo lleve capas blancas como también van con ornamentos blancos el señor arzobispo y sus asistentes por la solemnidad del día. Que con esta procesión se tenga por cumplida la del mismo día de la Anunciación, como ha sucedido en otras muchas ocasiones de semejante concurrencia. Que la procesión vaya por el lado de la epístola, nave de San Pablo, llevando delante la hermandad del Santísimo Sacramento del Sagrario, que llegando el cabildo a la nave de la Virgen de los Reyes, entre en la capilla Real solamente su Ilustrísima con los señores presbítero y diácono asistentes, yendo delante el pertiguero, segundarios y demás ministros del pontifical. Que la música cante el motete sub tuum presidicum. Que en el ínterin imponga su Ilustrísima incienso y turifique el altar de nuestra señora, y que acabado el motete, y dicho por los seises el versículo Ora pro nobis, diga su Ilustrísima la oración Concede nos famulos tuos sub media conclusione. Acabada la oración prosiga la letanía desde el Santo, en que cesó cuando entró su Ilustrísima en la capilla y empezó el motete la música. Que la imagen de Nuestra Señora se incorpore en la procesión y vaya en el mismo sitio y forma que suele ir en la procesión del 15 de agosto y ha ido en otra ocasiones de rogativa, acompañándola los capellanes reales con sus capas pluviales blancas. Que la procesión sea en la misma forma que se hace la del 15 de agosto, cantando la letanía. Que el repique de las campanas mientras dura la procesión sea de primera clase. Que la procesión entre por la puerta de San Miguel, que llegado el cabildo al coro y la imagen de Nuestra Señora al plano del altar mayor, finalice el señor arzobispo la letanía con sus preces y oraciones Ut in ritual en medio del altar mayor debajo de la gradas, acompañado de los señores asistentes, y estando en su lugar de pontifical los señores dignidades. Que acabada la letanía y quedándose su Ilustrísima en el mismo sitio del altar imponga incienso y se descubra el Santísimo Sacramento en forma regular con un repique solemne, como se hizo en el año de 1636 en otra rogativa a petición del Rey Felipe Cuarto, que después de haber hecho estación a la Iglesia de San Salvador para la misa que se dijo en Nuestra Santa Iglesia se descubrió el Santísimo Sacramento. Que en la misa pontifical se observe lo que en otras ocasiones, y que en la publicación de la indulgencias después del sermón se guarde lo mismo que se ejecutó en la misa de pontifical que se celebró en acción de gracias por la exaltación del papa Alejandro octavo. Acabada la misa, estando su Ilustrísima en medio del altar, se haga la rogativa en la forma habitual, diciéndose en el coro La ana sub tuum presidium y en el altar las oraciones que se dicen en las rogativas que se hacen en la capilla real. Que acabada la 
La noticia del nombre del nuevo Papa electo no tardó en llegar a la sede hispalense. El día 6 de agosto de 1691 se recibió una carta del arcediano de Écija y canónigo de la catedral don Gregorio Bastán y Arostegui donde anunciaba la buena nueva "de haber sido exaltado el día 11 de julio al sumo pontificado el eminentísimo cardenal don Antonio Pinatelli, napolitano", tomando el nombre de Inocencio XII. Como en anteriores ocasiones las celebraciones que se hicieron en Sevilla estuvieron a la altura de tan magno acontecimiento, y con este fin se leyó en el cabildo un auto fechado el 15 de noviembre de 1689 donde se recogían los agasajos y exaltaciones que se les había hecho a anteriores pontífices en la ciudad y así, poder celebrar de la misma manera la noticia en Sevilla, siendo de los citados los más relevantes los de Clemente IX, Clemente X e Inocencio XI, realizando "las demostraciones de gozo y alegría que es su costumbre en Sevilla". Siguiendo el protocolo se colocaron luminarias en la torre y se ordenó un triple repique de campanas que se repitió en las dos horas siguientes de la misma manera. Además, se engalanó el altar mayor con un rico frontal blanco para celebrar una festividad con aparato de primera clase, y en medio de dicho altar se colocó la tiara papal y llaves cruzadas sobre una urna de plata, manteniéndose el emblema expuesto durante todo el día hasta el cierre de la catedral por la noche. Debido al adorno y a los fuegos programados en la torre, se decidió oficiar maitines detrás de completas, para asegurar la asistencia de un mayor número de fieles. El cabildo nombró al arcediano de Reyna don Pedro Francisco Levanto, al canónigo don Bernardo de Urbina y al racionero don Joan de Miranda para que fuesen a informar al arzobispo de la feliz noticia y solicitar su consentimiento para que diesen comienzo los actos para la exaltación del pontífice. Palafox dio su aprobación, y saliendo del palacio arzobispal acompañado de la diputación comenzó un repique de campanas que duró hasta su entrada en la catedral con el boato que la ocasión requería. El maestro de ceremonias salió con sobrepelliz a la puerta de San Miguel a recibir con la mayor solemnidad posible a don Jaime de Palafox y Cardona y a los tres capitulares, y junto al provisor se hizo un llamamiento a todas las parroquias y conventos de la ciudad para que se realizase públicamente una fiesta de acción de gracias el 21 de agosto en la archidiócesis hispalense con motivo de la elección del nuevo Sumo Pontífice. Hasta ese día se darían tres repiques solemnes a las 12 de la mañana desde la Giralda, a los que responderían las campanas de todos los conventos e iglesias de la ciudad y sus arrabales. En la víspera de la celebración "se aderezó por la tarde la capilla mayor de primera clase de blanco con el frontal rico y la capilla de San Pedro con colgadura, y en medio de su altar se pongan sobre la urna pequeña de plata la tiara y llaves", y tras maitines se dieron otros tres repiques solemnes y se encendieron las luminarias en la torre. El día 21 se oficiaron solamente las horas menores, y tras la última se hizo una procesión a la que asistió el arzobispo vestido con sus pontificales, todo el cabildo con capas pluviales blancas, todo el clero de la ciudad, las cruces parroquiales y los beneficiados. Cuando el cortejo entró en la catedral se realizó "un rito de primera clase por las últimas naves de esta Santa Iglesia", y entonando el Te Deum laudamus se realizó una estación en la capilla de San Pedro, para finalizar posteriormente en la capilla mayor. Tras la misa el cabildo eclesiástico celebró una fiesta de acción de gracias costeada por la mesa capitular por la exaltación del papa Inocencio XII, a ella acudió al arzobispo y el cabildo secular, además de todo el pueblo para que "se hiciese esta fiesta con el regocijo popular y solemnidad que en esta Santa Iglesia se acostumbra". ${ }^{28}$

rogativa, canten la música Tantum ergo, y el Alabado, y se encierre a Nuestro Señor con repique solemne, diciendo su Ilustrísima la oración. Que encerrado Nuestro Señor prosigan en el coro sexta, nona y vísperas. Que en dicho día de la Anunciación por la tarde haya hora de siesta de dos a tres, y asistiendo a ella toda la música, cuatro veinteneros y cuatro capellanes que convidará el sochantre. Que a las tres empiecen las completas solemnes, y que acabadas éstas se lleve a Nuestra Señora en procesión a su capilla Real, con el mismo acompañamiento y forma que se observa el día 15 de agosto por la tarde, yendo delante la hermandad del Santísimo Sacramento del Sagrario. Que llegada la imagen a la Capilla Real, y estando presente todo el cabildo de rodillas, cante la música La letanía de Nuestra Señora, que se suele cantar en la octava de la Concepción. Y se finalice la función con la oración Concede nos famulos tuos".

${ }^{28}$ Idem: 82v, 83 y 87, en cabildos celebrados los días 6, 13, 17 y 20 de agosto de 1691. 
Las celebraciones por la exaltación del papa Inocencio XII se enturbiaron debido a una repentina enfermedad que sufrió el rey Carlos II. El lunes 20 de agosto de 1691 se tuvo noticia en Sevilla de que el Rey se encontraba "achacoso", encargándose una misa mayor asistida por el arzobispo y una rogativa por espacio de 9 días para pedir a Dios por la salud del monarca con el Santísimo descubierto. La misa y la rogativa se realizaron en la catedral, y se dio orden de informar a todas las parroquias y conventos de la archidiócesis del suceso para que en el mimo periodo de tiempo se sucedan oraciones rogando por la recuperación del Rey. ${ }^{29}$ A la semana de comenzar las preces se recibió la feliz noticia de la mejoría del Rey "tras el accidente que había padecido", y el cabildo dio las gracias a Dios por la salud de Carlos II y encargó para 29 de agosto una misa cantada y una oración en la capilla de la Virgen de los Reyes que también estaría presidida por el prelado. Además, el 1 de septiembre a medio día se hicieron tres repiques solemnes desde la Giralda, y al domingo siguiente se tocó durante una hora la campana de la torre por la tarde, de seis y media a siete y media de la tarde, y en acción de gracias se oficiaron en el coro prima, tercia, vísperas, la misa de la dominica, sexta, nona, y una procesión por las últimas naves de la catedral a la que asistió el cabildo al completo vestido con capas pluviales, el arzobispo con sus pontificales y llamados por éste acudieron todas las cruces y clero de las parroquias de Sevilla. Cuando el cortejo pasó por la Capilla Real se realizó una estación y se entonó el Te Deum laudamus. Mientras discurría la procesión las campanas de la torre tocaron repiques solemnes, terminando con la celebración de una misa para dar gracias a Santísima Trinidad con gloria, credo y sin sermón. Para celebrar la mejoría del Rey se proyectaron para ese día festejos en toda la ciudad, y entre otras manifestaciones "una máscara que transite por las calles de la ciudad", luminarias simples por las calles de la ciudad y dobles para iluminar las vías por donde pasarían las carrozas, además se quemó un castillo de fuegos de artificio en acción de gracias. El cabildo secular pidió al eclesiástico que colocasen luminarias también en la torre para los festejos, pero se declinó la petición. ${ }^{30}$

Finalizada la celebración por la mejoría del Rey, el 5 de septiembre de 1691, se tuvo noticia "del peligroso achaque que le había sobrevenido a la Reina Nuestra Señora que Dios guarde". El cabildo dictó que se oficiase una misa y una rogativa en el altar mayor de la catedral con el Santísimo descubierto por un periodo de ocho días "en la misma conformidad que se había hecho por la salud del Rey nuestro señor". Así se produjeron todos los actos celebrados con la presencia de don Jaime de Palafox y Cardona. La reina no mejoró y el cabildo pidió que se continuasen en la catedral las peticiones por la salud de la Reina durante ocho días más en la misma manera que se estaban realizando. Parece que fueron escuchadas las oraciones de la Iglesia de Sevilla, ya que acabados los ocho días de oración en el altar mayor, se recibió en respuesta de Madrid la noticia de la deseada mejoría de la Reina. La Diputación de Ceremonias determinó que se realizaran los festejos de la misma manera "que se hicieron en hacimiento de gracias por la memoria del Rey". El domingo 23 de septiembre se hizo una demostración pública por "la milagrosa mejoría de su majestad, en la misma conformidad y en las mismas circunstancias que se celebró este mes por la recuperada salud del Rey, cambiando solo el sermón predicado sobre la Santísima Trinidad por otro de Nuestra Señora", a los actos asistieron el cabildo de la ciudad y el arzobispo, encargándose de la oración de gratitud delante del Santísimo. El prelado estimó mucho el gesto del cabildo y manifestó su deseo de ayudar en todo lo le fuese posible. ${ }^{31}$

Los fastos en las celebraciones religiosas y profanas en la diócesis de Sevilla gozaron de gran esplendor y boato a lo largo de la Edad Moderna, siendo receptores de todas aquellas modificaciones que enriqueciesen el teatro barroco con gran solemnidad y siendo recibidas con gran alegría por la población secular. El arzobispo apoyó enérgicamente las iniciativas que llegaban desde Roma, así como las suyas propias, dotando económicamente estas festividades. Así, el viernes 18 de abril de 1692 el canónigo y representante del arzobispo don

\footnotetext{
29 Idem: 87v, en cabildo celebrado el 20 de agosto de 1691.

30 Idem: 90v-91 y 93r-94r, en cabildos celebrados los días 27 y 29 de agosto y 1 de septiembre de 1691.

${ }^{31}$ Idem: 95v, 98r y 105r, en cabildos celebrados los días 5, 10 y 19 de septiembre de 1691.
} 
Jerónimo de Abladía trasladó en nombre del prelado a la Diputación de Ceremonias una petición con el fin de que se admitiese "en esta Santa Iglesia y su arzobispado el rezo de Santo Domingo de la Calzada semidoble permisivo para el día 12 de mayo". El cabildo admitió la propuesta y además informó al arzobispo que se celebraría "la procesión de dicho Santo, que parece se hace en esta Santa Iglesia desde el año 1503, se haga siempre en el mismo día, así como se hace la de Santa Isabel reina de Hungría”. Un poco más tarde, el miércoles 1 de octubre de 1692, se recibió en Sevilla un breve del nuevo Pontífice fechado el 29 de diciembre de 1691 y leído en un cabildo ordinario presidiendo el deán en el que se concedía rito doble de precepto a san Francisco de Sales, celebrándose con dignidad de semidoble hasta el momento. La Diputación de Ceremonias delegó el documento en Abladia, para que el prelado pudiese despachar y publicar un edicto antes de que saliese de la ciudad a continuar su visita a las villas de la sierra norte del arzobispado como tenía previsto. Al día siguiente la Diputación se reunió con el canónigo para de estudiar el decreto que la Sagrada Congregación de Ritos había enviado y transformar el rito semidoble de precepto a la advocación de san Francisco de Sales en doble para toda la Iglesia Universal. Palafox apoyó en todo a los acuerdos a los que llegaron y se emitió su edicto como era costumbre. ${ }^{32}$

El domingo día 7 de junio de 1693 se produjo un hecho insólito que hizo tambalear literalmente a la diócesis de Sevilla. Dos movimientos de tierra muy bruscos en menos de dos horas causaron "unos temblores tan memorables y horrorosos que le parecía al arcediano de Sevilla debiera hacer el cabildo alguna demostración pública de rogativa". El cabildo eclesiástico mandó hacer una plegaria en la capilla de la Antigua desde esa misma tarde para pedir a Dios que no continuasen las sacudidas. Por lo inusual del suceso los capitulares desconocían el manual que debían aplicar para realizar una ceremonia de acción de gracias a Dios por evitar males mayores en Sevilla y en España, especulando sobre la capilla que debía acoger la celebración y sobre las formas que podían utilizarse. Tres días más tarde del movimiento sísmico se celebró un cabildo presidido por el arcediano de Sevilla donde se decidió que el domingo 14 de ese mes de junio se terminaría la rogativa con la celebración de una fiesta en acción de gracias, convocando una procesión que discurriría por las últimas naves de la catedral. El cortejo hizo una estación el la capilla de la Virgen de la Antigua, y allí el cabildo secular al eclesiástico se unieron en una oración. El maestro de ceremonias pidió al prelado a través del provisor del arzobispado su asistencia, y se hizo acompañar por su séquito personal, por todas las cruces parroquiales de la ciudad y por el clero de la diócesis al completo para dar mayor lustro al la fiesta. Además se ordenó que se hiciesen tres repiques solemnes en la torre, y "que el dicho día domingo ande la campana de prima de seis a siete, y que dicha prima y tercia se diga la misa de la dominica, y luego sexta y nona, y después la procesión y misa pro gratiarum actione". ${ }^{33}$

El miércoles, 15 de abril de a1693, se celebró un cabildo ordinario donde se nombró una diputación encargada de organizar las celebraciones para la inauguración y estreno de un retablo en la iglesia del convento de la encarnación de Sevilla. El canónigo don Antonio de Flores y León, visitador por el cabildo de la monjas de la encarnación, informó "como el retablo del altar mayor de dicho convento que se había renovado y dorado estaba ya casi acabado, y que para su estreno disponían dichas religiosas una suntuosa festividad y que pedía, y su señoría en su nombre al cabildo, y a su prelado que las honrase en ella". Los capitulares nombraron una diputación plena para que en su nombre se organizase la fiesta el primer día de esta festividad, y se ofrecieron para tal motivo el arcediano de Jerez don Juan de Florencia y Tebes, don Antonio Vidal Marín, don Bernardo de Sosa y Ubita y don Antonio de Flores y León. El arzobispo Palafox aceptó la invitación para presidir los actos, debido entre otras cosas, por la buena relación que tenía con la comunidad de religiosas de la Encarnación. $^{34}$

32 A.C.S., Autos Capitulares, 1692: Op. cit., 41v-42r, 111r y 114r, en cabildos celebrados los días 18 de abril y 1 y 3 de octubre de 1692.

33 A.C.S., Autos Capitulares, 1693: Op. cit., 37v-38, en cabildos celebrados los días 8 y 10 de junio de 1693.

${ }^{34}$ Idem: 30r, en un cabildo celebrado el 15 de junio de 1693. 
Una de las peores desgracias que amenazaban a la monarquía española era la falta de un sucesor a la corona que a la muerte de Carlos II accediese legítimamente al trono. Debido a la incapacidad del soberano para engendrar un hijo varón, en el año de 1693 el Rey encargó a la Iglesia de Sevilla un novenario para rogar a Dios un heredero que garantizase la permanencia de la dinastía de los Austria en los Reinos Hispánicos y la paz en los años venideros. Así, el día 21 de octubre el cabildo recibió una carta de la Reina en la que encargaba la consecución de unas rogativas a tal efecto que costearía el propio Carlos II. La contaduría de la catedral elaboró un informe donde se notificó al cabildo la cuantía de los gastos a los que ascendía el novenario, siendo de 1.037 reales de vellón. Por el alto importe de dinero que se libró se observa que los fastos de las celebraciones estarían a la altura de los gastos, y que el cabildo eclesiástico no escatimó en las muestras de afecto y obediencia hacía los monarcas. Debido a la importancia de las plegarias todos los actos fueron presididos por el arzobispo don Jaime de Palafox, siendo informado de las nuevas por los canónigos don Pedro Ruiz de Villadiego, don Juan Cornejo y don Clemente de Funes. A los actos concurrieron todos los miembros del cabildo secular, que fueron informados por otros tres canónigos, don Alonso Benito de Medina, don Nicolás Antonio de Conque y don Francisco de los Santos. Por este mismo motivo, el arzobispo prorrogó, con la bula pertinente del Papa, el jubileo en los siete altares que tenía designados en la ciudad, para que todo aquél que quisiere acudir a rezar por el destino de la monarquía a cualquiera de ellos recibiera indulgencias plenarias. ${ }^{35}$

Matute da noticia de cómo el arzobispo, el domingo 11 de julio de de 1694 celebró una visita a la catedral acompañado del arcediano de Sevilla, don Jerónimo de Guzmán y el canónigo don Alonso del Corro. Entrando por la Puerta de la Asunción con su caudatario, fue recibido por los capitulares en procesión en el trascoro, se reclinó para orar en un habitáculo dispuesto en el primer tramo de pilares y siguió la procesión hasta el altar mayor donde se ofició una misa. Acabada ésta, se hizo otra procesión de ánimas por la catedral hasta volver de nuevo al altar mayor, donde el prelado se vistió de medio pontifical y continuó la visita al Sagrario, capilla bautismal, sacristías, entre otras, acompañado de sus adjuntos cubiertos con capas pluviales. ${ }^{36}$ Es decir, todo se desarrolló de manera correcta y según se acostumbraba. El autor también menciona en otro episodio que el 19 de diciembre de ese mismo año don Jaime de Palafox consagró a don Vidal Martín, canónigo de la catedral como obispo de Ceuta en su palacio arzobispal. ${ }^{37}$

El lunes 21 de mayo de 1696 se reunieron los capitulares, presididos por el deán don Juan de Domonte y Erazo, con el fin de admitir los rezos de prima solemne en el día de la Santísima Trinidad. Esta celebración fue introducida por deseo del arzobispo don Jaime de Palafox en la sede hispalense y dotada económicamente por él mismo. La Diputación de Ceremonias anunció la propuesta del prelado, para que se realizasen los rezos el siguiente "domingo de la Santísima Trinidad". En la Iglesia de Sevilla no había una normativa precisa para este ceremonial, y tampoco "ejemplar adecuado por las primas solemnes que ya hay". Se investigó en el Martiriológio y en la calenda de la festividad para ver la manera en la que se obraba en otras Iglesias, porque el cabildo deseaba "concurrir a la loable intención de su Ilustrísima en tan piadosa dotación”. Por ello, el eclesiástico admitió la proposición, y a partir de ese año se celebraron los citados rezos, además se indicó que "se cante la dicha prima con toda la solemnidad y aparato, con villancicos, y al termino se recite el salmo qui cumque vult en canto llano a favor en do menor, con papeles a cuatro o a ocho pausado, y con la solemnidad que pide semejante día, dando en todo lo demás el estilo regular de las primas solemnes que se cantan en esta iglesia sin sacramentado, ni festejo ni otra novedad alguna". Dos días después se le notificó al prelado que el cabildo había aceptado la celebración, y agradeciendo su disponibilidad, respondió que se informaría del manual que se estilaba en semejantes ocasiones y del presupuesto económico que debía librar, como era costumbre en otras dotaciones similares. Una semana más tarde el deán dio cuenta al cabildo de la memoria

\footnotetext{
35 Idem: 73, en los cabildos celebrados los días 21 de octubre y 4 de noviembre de 1693.

36 MATUTE Y GAVIRIA, 1887: Op. cit., tomo I, 153.

37 Idem: tomo I, 82.
} 
de gastos y del manual de ceremonia que el arzobispo deseaba seguir en Sevilla, "y que el manual se gane en la conformidad que es estilo en las primas solemnes". El desarrollo de la devoción a la Santísima Trinidad vertebró principalmente las visitas pastorales que realizó a las iglesias de la diócesis, dotando a muchas de ellas de lienzos que exaltaban este misterio con el fin de divulgar su culto. ${ }^{38}$

Murió en Madrid el 16 de mayo de 1696 doña Mariana de Austria, segunda esposa de Felipe IV y madre del rey Carlos II. Doce días después el Ayuntamiento de Sevilla recibió una carta del presidente del Consejo de Castilla en la que se comunicaba la noticia, notificándole al cabildo eclesiástico la triste noticia el 1 de junio a través de una carta, con fecha de 25 de mayo. El 4 de junio contestó a la carta con gran pesar del cabildo, comunicando que se realizarían las correspondientes exequias por la muerte de la Reina madre. Consecutivamente, el deán de la catedral ordenó un doble de las campanas de la torre para informar a las iglesias, conventos y a la población civil del deceso. Dos días más tarde, el cabildo secular dio orden a la ciudad de Sevilla para que guardase luto oficial a partir del día 9 de ese mismo mes, "como siempre se había estilado en situaciones semejantes", y se informó al cabildo para que comenzase el ceremonial "que siempre ha hecho la Santa Iglesia en estos casos". El mismo día, se reunieron los capitulares y escucharon por diputación al secular que pedía que se realizase a su costa un túmulo en la catedral en memoria de la monarca, y que además fijase las fechas para realizar las oportunas exequias. Los canónigos don Pedro de Levanto, don Diego Cavallero y don Domingo Lorenzo fueron a informar a la ciudad que el cabildo eclesiástico había decidido señalar los días 18 y 19 de junio para la celebración de los actos fúnebres, aunque inmediatamente se oficiaría en la catedral un responso solemne en memoria de la reina madre oficiado por el arzobispo don Jaime de Palafox y Cardona, "y para ello se preparó un altar de primera clase con seis zapatas y cuatro blandones negros con cera amarilla. Se dispuso un pequeño aparato funerario formado por una alfombra sobre la que iba un paño de brocado amarillo con cenefas de terciopelo negro bordadas en oro; sobre ello iba una pequeña cama con dos almohadas y la corona de la capilla real; la iluminación estuvo a cargo de los blandones gigantes con cirios de cera blanca". Las exequias se celebraron finalmente en los días designados por el cabildo, oficiándolas el propio prelado y encargándose además del sermón. ${ }^{39}$

La débil salud del rey Carlos II hacía peligrar de una manera alarmante la estabilidad política y económica que había conseguido alcanzar España con el gobierno de los Austria. Así, el miércoles 19 de septiembre de 1696 se celebró un cabildo ordinario presidido por el deán, donde la Diputación de Ceremonias informó sobre la delicada salud del monarca, decidiéndose realizar una rogativa por su salud. El viernes 21 de ese mismo mes, cuando se celebraba la onomástica del apóstol san Mateo, se colocó el Santísimo Sacramentado en el altar mayor, con el mismo aparato y adorno que el día de la Ascensión de Cristo. Las campanas de la torre repicaron durante una hora, de seis y media a siete y media de la mañana, para hacer una llamada de atención y que acudiese el pueblo. En el coro de la catedral se reunieron los miembros del cabildo y se oficiaron las oras de prima y de tercia, continuándose con una procesión que finalizó con una misa dedicada a san Mateo. Luego se celebraron sexta y nona, estando expuesto el Santísimo mientras sonaba el Tantum ergo. Acto seguido, volvieron a repicar solemnemente las campanas anunciando una misa votiva pro in firmis de primera clase. Cuando acabó la misa se efectuó la rogativa, estando todavía el cabildo en el coro en la forma habitual. Finalmente, se recogió al Santísimo mientras sonaba de nuevo el Tantum ergo, esta vez acompañado de música y repique solemne. Al día siguiente, sábado 22

38 A.C.S., Autos Capitulares, 1696: 27, 28, 32r y doc. s/f inserto, en cabildos celebrados los días 21 y 23 de mayo, y 6 de junio de 1696. En el texto inserto en las Actas se detalla la memoria de gastos de la celebración de la dominica de la Santísima Trinidad, "para repartir entre los prebendados que asistieron, 12.000 maravedíes; a los dichos capellanes de coro, 1.500 maravedíes; a la veintena, 1.500 maravedíes; A los músicos, 5.000 maravedíes; al maestro de capilla, 1.000 maravedíes; al maestro de ceremonias, 102 maravedíes; a la fábrica, 4.500 maravedíes; sumando un total de 25.102 maravedíes".

39 BAENA GALLÉ, 1992: Op. cit., 53-55; además, A.C.S., Autos Capitulares, 1696: Op. cit., 30-31r y 32r, en cabildos celebrados los días 1, 4 y 6 de junio de 1696. 
y día de santa Marta, se repitió el mismo esquema de actos litúrgicos que el día anterior, con la salvedad de que la procesión que se hizo ese día fue en honor de la patrona de las cocineras y de las sirvientas, por lo que tras la misa de tercia y en honor de la santa, se celebró una comida costeada por el cabildo a la que asistieron el secular y el arzobispo, como era costumbre en ese día. El domingo 23 se realizó todo como en los dos días antecedentes, respetando la procesión dominical acostumbrada. Y que "por las tardes no haya más novedad, y se haga la rogativa regular en la capilla de nuestra señora de los Reyes", con tres misas solemnes diarias, sumando un total de nueve, y ofreciendo dos reales de plata en limosnas en cada una de ellas, que estarían presididas por diferentes dignidades de la Iglesia por orden de antigüedad. La primera de ellas fue encargada al deán y el resto a los capitulares, siendo la más solemne la oficiada por el arzobispo don Jaime de Palafox. El primer día, las misas estuvieron asistidas por "seis señores caperos y en los dos días siguientes cuatro señores canónigos". El prelado quedó encargado de avisar a las capillas, iglesias y conventos de la diócesis con el fin de que se hiciesen las mismas demostraciones "en la mejor forma que diese lugar la posibilidad de las parroquias y el número de clero y ministros que hubiere en ellas". Finalizados los tres días de rogativas, el lunes 24 el cabildo decidió continuar las oraciones pidiendo por la salud del rey Carlos por ocho días más, descubriendo el Santísimo después de la misa, y realizando una estación de penitencia en la Capilla Real. ${ }^{40}$

El lunes 22 de octubre de 1696, en medio de un momento extremadamente convulso entre el cabildo y el arzobispo, se reunieron los canónigos en su sala capitular, y llamados por su pertiguero, informó el deán que el hermano de don Jaime de Palafox y Cardona había fallecido en la ciudad de Zaragoza. La tensa situación que existía entre ambas partes en el momento de la muerte provocó que las muestras de afecto fuesen torpes y muy frías, limitándose a nombrar una diputación para que fuese a dar el pésame al prelado por la muerte del marqués de Ariza. Para tal efecto, cabildo eclesiástico designó al arcediano de Reina don Pedro de Levanto y a los canónigos don Juan de Loaysa y don Lope de Céspedes para que fuesen al palacio arzobispal y trasladarle su dolor. ${ }^{41}$

El lunes 29 de julio de 1697, en un cabildo ordinario presidido por don Pedro de Aranda y Guzmán, canónigo y arcediano de Sevilla, se dio noticia de la concesión de una prórroga para el jubileo de las cuarenta horas que se estaba celebrando en la archidiócesis de Sevilla, a petición del rey Carlos II al papa Inocencio XII. Un mes y medio más tarde, el maestrescuela y canónigo don Andrés de Ibarburu y Galdona informó al cabildo que debido a la precariedad de medios económicos en que se hallaba la fábrica, se veían obligados a hacer coincidir el citado jubileo con una de las dos octavas que celebraba la Iglesia de Sevilla en el transcurso del año, el de la Purísima Concepción o la del Cospus Christi, señalándole los tres últimos días de cualquiera de ellas. El maestrescuela sugirió como mejor opción la octava del Santísimo Sacramento, argumentando "ser el jubileo concedido a este santísimo misterio", Y que de determinarlo así podría el cabildo nombrar a una diputación para que se lo participase al arzobispo. ${ }^{42}$

El lunes 18 de octubre de 1700, el deán de la catedral don Juan Domonte y Erazo, tras las rogativas que se estaban realizando por la salud del rey Carlos II, informó al cabildo que en la ciudad de Roma había fallecido el Papa Inocencio XII el día 27 de de septiembre. Al recibir la noticia, se celebró un responso rezado, oficiado por el deán y asistido por el maestro de ceremonias y un colegial que portaba el misal. Al terminar, se ordenó el toque de la campana mayor sesenta veces, y que en un periodo de veinticuatro horas se repitiesen los tañidos cada sesenta minutos. En consecuencia, también se avisó al provisor para que ordenase al resto de las iglesias que doblasen las campanas en contestación a la torre de la catedral. Por la tarde se ofició un responso entre los dos coros que se acompañó de música de órgano, siendo adecuado este espacio con una alfombra que cubría todo el pavimento y

40 Idem: 47-48r, en cabildos celebrados los días 19 y 24 de septiembre de 1696.

41 Idem: 54v, en cabildo celebrado el día 22 de octubre de 1696.

42 A.C.S., Autos Capitulares, 1697: Op. cit., 86r y 106, en cabildos celebrados los días 29 de julio y 16 septiembre de 1697. 
una tarima en el centro sobre la cual se dispusieron dos cojines y los emblemas del papado encima. Se acotó por cuatro candelabros de plata "gigantes" en cada uno de sus ángulos, y se adornó el altar mayor de primera clase con un frontal negro. El 5 de noviembre se reunió el cabildo y decidió que las honras en honor del Papa Inocencio XII se oficiarían los días 15 y 16 de ese mes, para ello se ordenó al maestro de fábrica que dispusiese todo lo necesario para la elevación del túmulo en la manera acostumbrada. Para informar al prelado y al cabildo secular se nombró una diputación formada por el arcediano de Reina don Pedro Levanto, al canónigo don Fernando Montesdoca y al racionero don Conrrado Montes, y se dispuso que el presidente de capillas avisase a todo el clero de la ciudad para que acudiese los días fijados para las honras a la iglesia del Sagrario. Ese mismo día confirmó el arzobispo Palafox su asistencia y celebró las demostraciones que el cabildo había dispuesto en memoria del difunto Papa, asegurando que presidiría los actos, como era costumbre. ${ }^{43}$

Una repentina noticia llegó a la ciudad de Sevilla cuando se estaban celebrando los actos luctuosos en memoria del papa Inocencio XII. Se iniciaba el siglo XVIII con la desaparición de un monarca y la extinción de una dinastía que había gobernado en España durante cerca de dos siglos, dejando unos problemas dinásticos de difícil solución. El rey Carlos II murió sin descendencia el 1 de noviembre de 1700, dejando como heredero en su testamento a Felipe de Borbón, duque de Anjou y nieto de Luís XIV de Francia, dando lugar a graves problemas dinásticos con el advenimiento de los Borbones a España y a la Guerra de Sucesión. El 8 de noviembre llegó a Sevilla la noticia del fallecimiento del Rey a través de una carta del presidente del Consejo de Castilla dirigida al Ayuntamiento de la ciudad. Se informó al cabildo eclesiástico y se solicitó su ayuda en todo lo necesario para la celebración de las exequias, por lo que se ordenó el doble de campanas de la Giralda correspondiente y el responso solemne. Las exequias se celebraron los días 1 y 2 de diciembre, tras recibir carta de la reina el día 15 de noviembre. Se utilizó el túmulo que se levantaba para la honras de los pontífices en la catedral de Sevilla, por estar montado previamente entre los dos coros por la reciente desaparición del Pontífice, y se dispuso el altar mayor con el adorno necesario para las celebraciones de primera clase. Tanto la vigilia como la misa estuvieron a cargo del arzobispo Palafox vestido de pontifical, delegando el sermón en don Luís de Flores, canónigo doctoral de la catedral. ${ }^{44}$

Las honras fúnebres del monarca español quedaron disueltas por la elección de un nuevo Papa en Roma. El 30 de diciembre de 1700 se celebró un cabildo extraordinario, donde el deán informó con toda solemnidad sobre el contenido de una carta que le había llegado de la corte de Madrid, firmada por el arcediano de Niebla don Gregorio Bastán y Arostegui. El canónigo dio noticia al cabildo eclesiástico de haber sido nombrado Pontífice el cardenal romano don Juan Francisco Silvano, tomando el nombre de Clemente XI, por haber sido elegido en el día 23 de ese mes, cuando la Iglesia festejaba la onomástica de san Clemente mártir. Tras leer los manuales sobre el ceremonial que se debía seguir, se decidió que las celebraciones se llevarían a cabo el 18 de enero de 1701, e inmediatamente se ordenaron tres repiques solemnes de todas las campanas de la Giralda y la preparación de la capilla mayor, "con aderezo de primera clase, poniendo un frontal blanco en el altar mayor, sobre el cual se colocaron los símbolos papales sobre una urna de plata", hasta que llegase esa fecha. En las vísperas de la celebración se dieron tres repiques solemnes, y en honor del nuevo Papa se ordenó que la capilla de san Pedro "se aparate y se adorne con una colgadura rica, colocando en medio de su altar sobre una urna de plata la tiara y las llaves, y que se digan los maitines por la tarde, y a la oración se repitan los tres repiques en la torre, y en las azoteas de dicha torre se pongan luminarias. El ceremonial duró todo el día, por lo que el cabildo aplazó todos sus compromisos y actos que se tenían previstos. A partir de las doce de la mañana del día 18 y hasta la hora de la oración las campanas doblaron cada hora, y por la

43 A.C.S., Autos Capitulares, 1700: Op. cit., 81r, 84 y 90, en cabildos celebrados los días 4 y 18 de octubre, y 5 de septiembre de 1700 . 57.

${ }^{44}$ Idem: 91r, en un cabildo celebrado el día 8 de noviembre de 1700; BAENA GALLÉ, 1992: Op. cit., 55- 


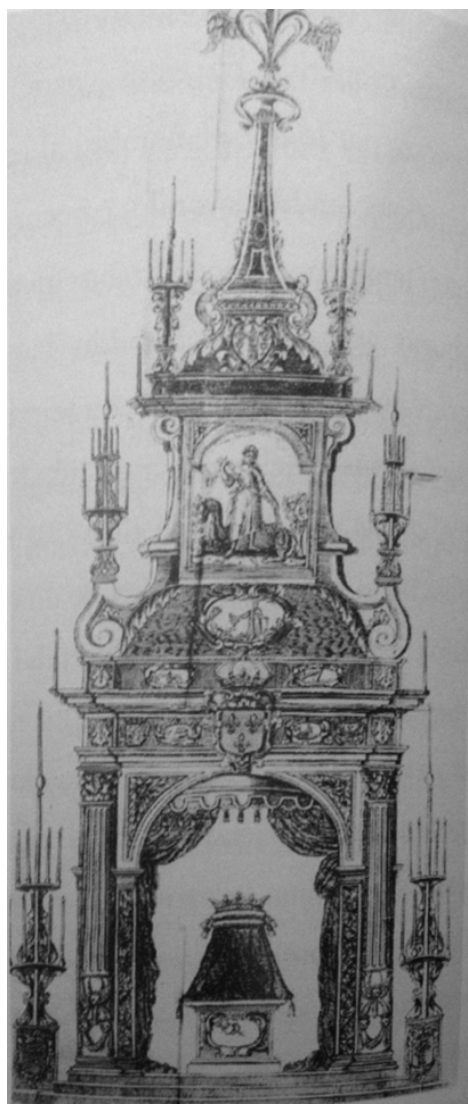

Fig. 2. Tumulo para las exequias de la Reina María Luisa de Orleans en la Catedral de Sevilla, en Breve relacion de las exequias de la muy Noble y muy Leal Ciudad de Sevilla dedicó a su Reina Doña María Luisa de Borbón, que sea en gloria en el día 30 de marzo de 1689. En Sevilla: por Juan Francisco de Blas. Biblioteca Nacional. Madrid.

noche se volvieron a encender "luminarias en la torre y azoteas de esta Santa Iglesia". Tras el oficio de oras, el cabildo organizó una procesión solemne con capas pluviales blancas por la últimas naves de la catedral, a la que asistieron todos los capitulares acompañados de todas las cruces de las iglesias de la ciudad, los beneficiados y el clero de la diócesis. El cortejo estuvo asistido de música y un coro de canto llano que acompañó a los clérigos mientras el cabildo cantaba el Te Deum laudamus hasta llegar a la capilla de san Pedro, donde se hizo una estación para rezar por el buen gobierno en el ministerio del nuevo Pontífice. Acabada la oración, se elevó de nuevo el Te Deun laudamus hasta que acabó la procesión en el altar mayor, donde se celebró una misa solemne con sermón para concluir los actos, y al que previamente se había invitado al arzobispo Palafox a dictarlo. Para tal motivo, se envió una diputación al palacio arzobispal formada por el arcediano de Niebla don Francisco Lelio, el canónigo don Fernando de Santillán y el racionero don Antonio Toro, para que fuesen a ver al prelado y le hiciesen la propuesta, ya que tenían noticia del mal estado de salud en el que se encontraba. Además, también se invitó al cabildo secular, para que asistiesen en acción de gracias. El maestro de ceremonias avisó al provisor de capillas para que ordenase "que todas las parroquias y conventos de esta ciudad y sus extramuros, concurran con todos los repiques de la torre". 45

El día 11 de febrero de 1701 se celebró un cabildo extraordinario, en el que el deán informó que el procurador mayor de Sevilla le había notificado la llegada de Felipe V a España. Para celebrar esta noticia, el cabildo eclesiástico mandó poner luminarias durante tres noches consecutivas en la torre, desde el día 12 hasta el 14, aceptando la propuesta del Ayuntamiento de correr con todos los gastos que ocasionasen y de asistir a lo festejos acompañados de un cortejo de danzantes, como lo habían hecho en las procesiones del Corpus,"por ser esta fiesta digna de celebrarse con quanto regocijo fuere posible". Además,

45 Idem: 105v-106r, en cabildo celebrado el 30 de diciembre de 1700. 
el cabildo de la ciudad invitó a los capitulares y al arzobispo a una celebración que tenía prevista esa misma tarde en la Casa Profesa de la Compañía de Jesús "en hacimiento de gracias" por el advenimiento del monarca. Sin embargo ni el cabildo ni el prelado acudieron, anunciando que no podrían asistir por diferentes motivos, siendo los del arzobispo los continuos achaques que sufría. Matute indica cómo, a pesar del estado de salud del prelado, el 12 de febrero 1701 presidió una misa de pontificales para dar gracias a Dios por la entrada en España del nuevo rey Felipe V, el 22 de enero de ese mismo año. ${ }^{46}$ Antes del oficio se celebró una procesión de capas por las últimas naves de la iglesia, y cantando el Te Deum laudamus se hizo una estación en la Capilla Real, acabando con la citada misa de primera dignidad "en hacimiento de gracias a su Divina Majestad por la feliz llegada de nuestro católico monarca don Felipe Quinto a sus dominios de estos reinos de España". ${ }^{7}$

A pesar de su debilidad, el arzobispo Palafox continuaba acudiendo a diferentes actos públicos, mostrando el detrimento de la situación física en la que se encontraba y que hacían vaticinar el peor de los desenlaces. Sin embargo, su responsabilidad como prelado hizo que atendiera a todas sus responsabilidades hasta sus últimos días, acelerando así el proceso de la enfermedad que padecía. El 9 de mayo de 1701 llegó a Sevilla una bula del nuevo Papa, con fecha de 18 de abril, concediendo a esta ciudad un jubileo de dos meses para celebrar el Año Santo. En Sevilla no se celebrara un acontecimiento así desde los años 1652 y 1676, por lo que se consultaron los manuales para ver la manera en que tenían que celebrarse los actos con la mayor solemnidad posible. Así, se decidió que el 16 de mayo, segundo día de Pascua del Espíritu Santo, se publicaría un auto, que se dejaría antes del sermón y a vista de todos, en el púlpito de la capilla mayor, anunciando que el miércoles 18 se celebraría una procesión general con todo el clero y las órdenes religiosas de la diócesis, y tras hacer un recorrido por el interior de la catedral saldría a la calle, discurriendo por las calles Francos y Chicarreros, hasta llegar al convento de San Francisco, volviendo a la catedral por la calle Génova, ya que la plaza del Salvador estaba levantada por las obras de la iglesia. Se nombró una diputación formada por el arcediano de Reina don Pedro Francisco Levanto, por el canónigo don Diego Cavallero de Mejías y por el racionero don Antonio Toxo para que fuesen a avisar al arzobispo y al cabildo de la ciudad, con el fin de que pudiesen asistir y participar en los actos. ${ }^{48}$

Para concluir, El lunes 12 de diciembre se convocó un cabildo extraordinario, presidido por el deán de la catedral don Juan Domonte y Erazo para disponer que en los días 19 y 20 de ese mismo mes de diciembre se celebraran las honras fúnebres en memoria de don Jaime de Palafox y Cardona. Para ello se destinó una partida de diez reales de plata que se entregaría a sus albaceas de mano del maestro de ceremonias don Adrián Eisú. En este mismo día, se decidió en cabildo extraordinario que la Diputación de Ceremonias se dispusiese a hacer una petición al monarca para que se nombrase un nuevo prelado para la sede hispalense. ${ }^{49}$ En contra de los deseos del prelado, se ofició una misa de cuerpo presente en la catedral en su memoria el día 5 de diciembre celebrada por el padre Francisco de Acevedo de la Compañía de Jesús. ${ }^{50}$ Se celebraron otras exequias, además de las previstas en la catedral el día 19, en el convento de religiosas capuchinas dirigidas por fray Alonso Álvarez y Palma, del Carmen de Observancia cuatro días más tarde. En la aprobación dada por el padre agustino fray Tomás de la Cuesta para la impresión del primero de estos panegíricos reiteró el deseo del arzobispo de que su muerte fuese celebrada con toda humildad y recato, siguiendo el ejemplo de su vida: "No quería sermón de honras; aunque en esto se sujetó a lo que dispusiese su amado

\footnotetext{
46 MATUTE Y GAVIRIA, Justino, 1887: Op. cit., 6.

47 A.C.S., Autos Capitulares, 1701: Op. cit., 12, en dos cabildos celebrados uno por la mañana y otro por la tarde, el día 11 de febrero de 1701.

48 Idem: 31v, en cabildo celebrado el día 9 de mayo de 1701.

49 A.C.S., Autos Capitulares, 1701-1702: Op. cit., 121v.

${ }_{50}$ Matute hace responsable de este sermón celebrado en la catedral en la memoria del arzobispo a fray Juan Machado, ministro del real convento de la Santísima Trinidad. MATUTE Y GAVIRIA, 1887: Op. cit., tomo I,
} 13. 
cabildo. No le parecía tener virtudes verdaderas que pudiesen predicarse, por más grandes que eran en sí, a sus ojos parecían tan pequeñas que se le escondían de su vista". ${ }^{51}$

\title{
FUENTES MANUSCRITAS
}

\author{
ARCHIVO DE LA CATEDRAL DE SEVILLA
}

Libros de Actas Capitulares del Cabildo de la Santa Iglesia Catedral de Sevilla de los años 1685 a 1693, 1696 a 1697, 1700 a 1702. Fondo Capitular, Sección Secretaría, Serie Autos Capitulares.

Dotación y memoria de gastos para la fiesta de Santa Rosalia en la Catedral de Sevilla, Fondo Administración, Sección Gobierno, Serie Asuntos Despachados, Legajo 3, 1655-1700.

\section{ARCHIVO GENERAL DEL ARZOBISPADO DE SEVILLA}

"Carta de don Pedro de Ormaechea Garai de Mendiola a don Jaime de Palafox y Cardona sobre diversos temas, entre ellos sobre el expolio del arzobispo Spínola, en Madrid con fecha 1 de septiembre de 1693" en Correspondencia escrita por el arzobispo don Jaime de Palafox y Cardona (1685- 1695), Fondo arzobispal, Sección II Gobierno, Serie Asuntos Despachados, Legajo 15.954, Expediente 1, doc. s/f.

"Carta de don Pedro Valero a don Jaime de Palafox y Cardona sobre el palio de su Ilustrísima, con fecha de Madrid 10 de abril de 1685”, en Correspondencia escrita por el arzobispo don Jaime de Palafox y Cardona (1685-1695), Fondo arzobispal, Sección II Gobierno, Serie Asuntos Despachados, Legajo 15.954, Expediente 1, doc. s/f."

"Carta de don Pablo Resi del Castillo al arzobispo de Sevilla, don Jaime de Palafox y Cardona, con fecha de 22 de mayo de 1685", en Correspondencia escrita por el arzobispo don Jaime de Palafox y Cardona (1685- 1695), Fondo arzobispal, Sección II Gobierno, Serie Asuntos Despachados, Legajo 15.954, Expediente 1, doc. s/f.

"Carta de don Pablo Ressi a don Jaime de Palafox y Cardona sobre diferentes temas, con fecha de Madrid 16 de septiembre de 1687", en Correspondencia escrita por el arzobispo don Jaime de Palafox y Cardona (1685-1695). Fondo arzobispal, Sección II Gobierno, Serie Asuntos Despachados, Legajo 15.954, Expediente 1, doc. s/f.

\section{ARCHIVO HISTORICO DE PROTOCOLOS NOTARIALES DE SEVILLA}

Testamento de Don Jaime de Palafox y Cardona (1701). Sección: Protocolos Notariales, 1701/of-24/L2.

\section{FUENTES DOCUMENTALES}

Acebedo, F. de S.J.: Sermón el día cinco de diciembre de 1701 en el entierro y cuerpo presente del Ilustrísimo y Reverendísimo Don Jayme de Palafox y Cardona, Arzobispo de Sevilla (...). En Sevilla, por Lucas Martín de Hermosilla, impresor y mercader de Libros.

51 ACEBEDO, 1701; ÁLVAREZ Y PALMA, 1701. 
Álvarez y Palma, Fr. A.: Sermón que en las exequias que al Ilustrísimo y Reverendísimo Señor Don Jayme de Palafox y Cardona, Arzobispo de Sevilla bizo el religiosísimo convento de Santa Rosalía, de religiosas capuchinas (...). En Sevilla, por Lucas Martínez de Hermosilla, impresor y mercader de libros.

Blas, F. de: Breve relación de las exequias que la muy Noble y muy Leal Ciudad de Sevilla dedicó a su Reina Doña María Luisa de Borbón, que sea en gloria, en el día 30 de marzo de 1689. En Sevilla: por Juan Francisco de Blas.

San Bernardo fray Juan, Vida y milagros de Santa Rosalia Virgen. En Sevilla: por Thomás López de Haro, 1689.

\section{FUENTES BIBLIOGRÁFICAS}

Arenillas, J.A.: "Busto relicario de Santa Rosalía", en catálogo de la exposición La imagen reflejada. Andalucía espejo de Europa, Cádiz. (2007)

Baena Gallé, J.M.: Exequias reales en la Catedral de Sevilla durante el siglo XVII, Sevilla. (1992)

Matute y Gaviria, J.: Anales eclesiásticos y seculares de la muy noble y muy leal ciudad de Sevilla... que contienen las más principales memorias desde el año de 1701... hasta el de 1800, Tomo I, Sevilla. (1887).

Morgado, J.S.:Prelados sevillanos ó episcopologio de la Santa Iglesia Metropolitana y Patriarcal de Sevilla: con noticias biográficas de los señores Obispos Auxiliares y otros relacionados con esta Santa Iglesia / que escribió... José Alonso Morgado. Tipografía de Agapito López, Sevilla. (1906)

Ortiz De Zúñiga, D.: Anales eclesiásticos y seculares de la muy noble y muy leal ciudad de Sevilla ... I Por Don Diego Ortiz de Zúñiga ..., ilustrados y corregidos por D. Antonio María Espinosa y Carcel; Imprenta Real, Madrid, Tomo V. (1769) 